\title{
Classification of karst springs for flash-flood-prone areas in western Turkey
}

\author{
Muhterem Demiroglu \\ Department of Geological Engineering, Istanbul Technical University, 34469 Istanbul, Turkey \\ Correspondence to: Muhterem Demiroglu (demiroglum@itu.edu.tr)
}

Received: 5 January 2016 - Published in Nat. Hazards Earth Syst. Sci. Discuss.: 28 January 2016

Revised: 30 May 2016 - Accepted: 8 June 2016 - Published: 27 June 2016

\begin{abstract}
Flash floods are caused by heavy rainfall that has become more frequent. They are more prominent in lowstorage karst regions, although karst terrain often acts as a natural flood control particularly when it is bare and dominated by conduits. A study using a hydrogeochemical approach and assessing data from several springs in different carbonate rock in western Turkey has made it possible to classify karst aquifers based on their response to heavy rainfall events. According to this aim, physico-chemical measurements in wet and dry seasons and discharge rates in springs are compared in order to explain aquifer characteristics. Groundwater samples have a $\mathrm{pH}$ ranging from 6.3 to 8.9, temperature $(T)$ varying from 7 to $35^{\circ} \mathrm{C}$ and electrical conductivity (EC) ranging from 140 to $998 \mu \mathrm{cm}^{-1}$. Groundwater samples with high EC, high $T$ and low dissolved oxygen (DO) represent the deep circulating water, while low EC, low $T$ and high DO are linked to the shallow circulating water. Lower variability between wet and dry seasons reveals that fracture permeability is predominantly controlled by diffuse groundwater flow with low or high storage, and conduit permeability with high storage. However, variability of the physico-chemical characteristics is higher in a conduit permeability with low storage. These types of aquifers with high transfer capability, predominantly controlled by turbulent groundwater flow, affect flash floods.
\end{abstract}

\section{Introduction}

Flash floods are deadly and costly natural disasters worldwide. A special kind of flash floods is the karst flash flood. Karst aquifers provide $20-25 \%$ of high-quality groundwater for drinking water in the world. Therefore, they are par- ticularly important for water management. Karst terrain are fragile and vulnerable to a variety of hazards (Parise, 2015), including flash floods due to heavy rainfall. They occur when intensive short-duration rainfall is recorded, such as $571 \mathrm{~mm}$ on 6 December 2004 in Sardinia, Italy (Cossu et al., 2007), or $200.5 \mathrm{~mm}$ on 12 September 2009 in Ayamama Creek, Istanbul, Turkey (Bacanli et al., 2011). Flash floods are intensified when heavy rainfall is combined with rapid snowmelt or man-made disasters (e.g. dam failure) on steep terrain with excessive antecedent precipitation and thin, bare and/or impermeable soil or covers (Bonacci et al., 2006).

Due to characteristics of groundwater flow in karst terrain, flash floods are strongly different from those in nonkarst terrain. Karst terrain can often be considered as natural flood control, especially when it is bare and dominated by conduits. However, flash floods can become prominent in low-storage karst regions. Furthermore, karst groundwater watersheds often do not coincide with topographic divides, to indicate just one of the main differences between karst hydrology and other environments (Parise and Gunn, 2007; Parise et al., 2015). Delineation of drainage basins and drainage divides is complicated by the overlap of catchment areas where perched vadose flow crosses phreatic divides, and by the shifting of divides with time as the flow stage varies (Palmer, 2010). Divergent flow and disjunct contributory areas provide further complexity (Gunn, 2007).

Recharge of karst aquifers is described as infiltration - inflow to increase the groundwater level, and deep inflow to create a groundwater reservoir. Infiltration has two different forms: areal or spatial diffusive infiltration flows, passing directly into the groundwater reservoir. The spatial groundwater recharge process is diffusive, in which water reaches the groundwater table as a laminar flow through the intergran- 
ular unfractured bedrock and fractures (Shuster and White, 1971). The other form of recharge (point infiltration) passes via karst structures, such as caves and sinkholes. It depends on the pipe-like structures (conduits) in which flow is dominantly turbulent. The minimum diameter of karst conduits or fractures in which turbulent flow could exist should be greater than 5 to $15 \mathrm{~mm}$ (Bonacci et al., 2006).

Duration, intensity and type of precipitation are important factors which affect the recharge directly. The altitude of the region under consideration is also considerably important (Sutcliffe, 2004). In karst terrain, point infiltration and sudden rainfall are correspondingly effective. Studies indicate that less than $5 \%$ of annual effective rainfall becomes groundwater recharge in non-karst regions, whereas recharge to karst aquifers is in excess of $80 \%$ of effective rainfall. For instance, in karst regions in Saudi Arabia, $47 \%$ of the average rainfall disappears at the intersections of dolines and cracks (Milanovic, 1981). According to De Vries and Simmers (2002), in Portugal, a dry and hot summer-climate, $150-300 \mathrm{~mm}(27-55 \%)$ of the $550 \mathrm{~mm}$ annual precipitation infiltrates in karstic dolomite and marble regions. Similar values are reported for karstic aquifers in Israel, a Mediterranean climate (Issar and Passhier, 1990). In different regions of former Yugoslavia, infiltration is calculated to be between 70 and $90 \%$ (Milanovic, 1981). In Turkey, in Tecer limestone (Sivas-Ulaş region in eastern central Anatolia), infiltration has a percentage as high as 55\% (Ekemen and Kacaroglu, 2001). The annual effective infiltration of the Gradole catchment in Croatia is between 36 and $76 \%$ (Bonacci, 2001), while it is between 60 and $90 \%$ for the mountainous karst regions in Switzerland (Malard et al., 2016). Similarly, in the Maiella aquifer in Italy, it is $900 \mathrm{~mm}(62 \%$ of $1450 \mathrm{~mm}$ of total annual rainfall) (Fiorillo et al., 2015b).

In general, the frequency or intensity of heavy rainfall events have increased over the midlatitude land areas of the Northern Hemisphere since 1901 (with a medium confidence before and a high confidence after 1951) (IPCC, 2013). According to the country report presented by the Turkish government and the United Nations Development Programme (UNDP), precipitation decreases along the Aegean and Mediterranean coasts and increases along the Black Sea coast of Turkey. Central Anatolia shows little or no change in precipitation (OECD, 2013). The most prominent result of the climate change data is that the number of days with excessive precipitation has been increasing in Turkey, which usually causes extreme floods. Even in regions where annual rainfall is decreasing, there is a trend for a higher amount of rain that reaches the ground in heavy downpours (CCSP, 2008; Karl et al., 2009).

Even if cumulative precipitation has increased, the groundwater recharge may have been less in diffuse flowdominated aquifers (Williams and Lee, 2008). In other words, the same amount of rainfall does not recharge aquifers as in the past because of change in rainfall intensity and its type as stated by Fiorillo et al. (2015b) who explained this response by an increase in evapotranspiration due to an increase in temperature. Unlike other aquifers, vertically oriented karst features collect and quickly transport water from the surface to the underground fluvial system. Because high-intensity rainfall is able to infiltrate fast enough before evaporating (Williams and Lee, 2008), practically all rainfall quickly penetrates into the karst underground system, where it fills karst voids of different dimensions, and flows under the effect of gravity (Bonacci et al., 2006). In these systems, flow primarily occurs rapidly in large fissures through irregular conduits known as quick flow or fast flow systems. Quick flow comprises stream sink water and percolation from closed depressions, while baseflow includes slow percolation from areas not drained by depressions (Fiorillo, 2009). Therefore, it can be noticed and expected that higher recharge in limestone dominated by conduits is due to heavy rainfall. However, it should be mentioned that an accurate and reliable estimation of recharge into karst aquifers is difficult because of their heterogeneous local structures (Bonacci, 2001; De Waele and Parise, 2013; Fiorillo et al., 2015a; Bakalowicz, 2015).

Developed karst sinkholes allow fast percolation of up to $80 \%$ of heavy rainfall into the aquifer. However, the very low storage combined with the high transmissivity means that most of the recharge will not be retained by the karst system, but will rapidly flow out (to springs, rivers, lakes, sea). The fast response of water level to the rainfall combined with the capability of karst systems to transmit groundwater increases flooding quickly (Williams and Lee, 2008).

Numerous studies have been conducted to determine aquifer characteristics of the discharging springs using their physico-chemical parameters, since each reservoir will have a characteristic chemical signature (Aquilina et al., 2005). Chemical characteristics of an aquifer are functions of residence time and flow conditions in the aquifer (Freeze and Cherry, 1979). Changes in the quantity and quality of the discharge of karst springs are largely caused by recharge parameters in the recharge area, such as rainfall and snowmelt (i.e. autogenic recharge), and point infiltration of streams (i.e. allogenic recharge) as well as lithology, hydraulic conductivity and residence time of aquifers that also affect changes. As a matter of fact, Shuster and White (1971), Atkinson (1977), Aydin (2005) and Demiroglu (2008) argued that the reason for the change observed in the spring discharges was the recharge type or flow type (diffuse or conduit) with high or low storage. A high number of studies have been done to define aquifer characteristics using physicochemical measurements (Shuster and White, 1971; Raeisi and Karami, 1997; Massei et al., 2007; Raynaud et al., 2015) by considering only one or a few physico-chemical parameters that characterize groundwater, which has the potential to lead to an erroneous interpretation of the hydrodynamics of the karstic catchment draining into the spring (Chicanoa et al., 2001; Massei et al., 2007). 


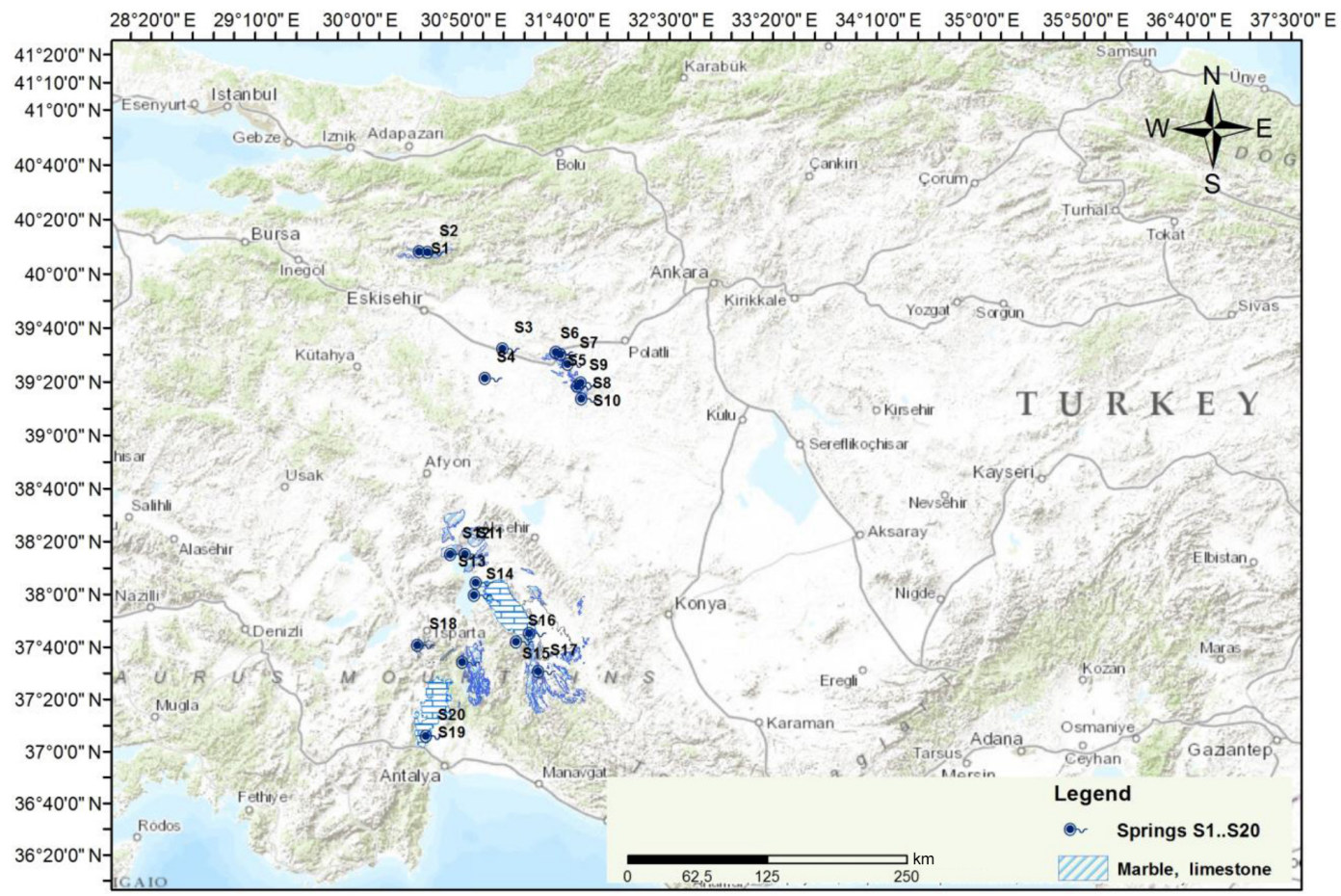

Figure 1. Location map of the study area and springs.

This study aims to classify karst aquifers based on their response to heavy rainfall events, by using a hydrogeochemical approach, assessing data from several springs in different carbonate rock in western Turkey. With this approach, it is expected that flood-prone areas can be defined on the basis of lithological and structural features of karst terrain.

\section{Study area and hydrogeology}

Karst aquifers with Paleozoic marble, Mesozoic limestone and Neocene limestone were chosen from western Turkey to understand aquifer characteristics for a possible classification in terms of their responses to heavy rainfall. All springs are shown in Fig. 1, with coordinates and elevations given in Table 1. Karst features of western Turkey demonstrate the tectonic, lithologic and climatic specificity underground flow movement, and chemical characteristics of groundwater $(\mathrm{Gu}-$ nay et al., 2015).

Springs are organized in three groups. The first group of springs (S1 Döskaya, S2 Nardin), located in the central Sakarya basin (Fig. 2), recharge and discharge from Jurassic Bilecik limestone. In this area, the Harmankoy-Beyyayla Karst System (HBKS), studied by Aydin (2005), forms the highlands in the Central Sakarya Basin. The HBKS is located in Bilecik and Eskişehir and extends over a surface area of $49.5 \mathrm{~km}^{2}$. The recrystallized and chert carbonate rock, known as Jurassic Bilecik limestone, overlays the metamorphic basement. It has a thickness of approximately $100 \mathrm{~m}$ of
Table 1. Location of springs.

\begin{tabular}{llcrr}
\hline No. & Spring & $x$ & $y$ & $z$ \\
\hline S1 & Döskaya & 289415 & 4445794 & 801 \\
S2 & Nardin & 295328 & 4445399 & 926 \\
S3 & Kaymaz & 345373 & 4378055 & 1015 \\
S4 & Sakarbasi & 332776 & 4357779 & 860 \\
S5 & Babadat & 382267 & 4374873 & 917 \\
S6 & Nasrettin Hoca & 385292 & 4373481 & 943 \\
S7 & Çardak Hamami & 390127 & 4366839 & 925 \\
S8 & Subaş1 & 399217 & 4353611 & 961 \\
S9 & Çukurçeşme & 396769 & 4351171 & 1011 \\
S10 & Yeniçıkr1 & 399431 & 4342506 & 887 \\
S11 & Tırtar & 316187 & 4235908 & 926 \\
S12 & Gencali & 306013 & 4236098 & 926 \\
S13 & Yenice & 323511 & 4215749 & 925 \\
S14 & Yeşilköy & 322084 & 4207189 & 952 \\
S15 & Pınarbaş1 & 360494 & 4179515 & 1127 \\
S16 & Pınargözü & 350959 & 4173656 & 1536 \\
S17 & Adakoy-Pınarbaş1 & 366447 & 4152589 & 1138 \\
S18 & Sagalassos & 281152 & 4173099 & 1591 \\
S19 & Kırkgözler 1 & 285415 & 4108347 & 300 \\
S20 & Kırkgözler 2 & 285415 & 4108347 & 300 \\
\hline
\end{tabular}

karstified layers (Aydin et al., 2013). It has a well-developed pipe-like karstic structure ranging from $1 \mathrm{~cm}$ to a few tens of metres, where groundwater flows in conduits is in turbulent regime. Calculated storage is between 2 and $5 \times 10^{6} \mathrm{~m}^{3} \mathrm{yr}^{-1}$ for Döskaya and Nardin springs. 


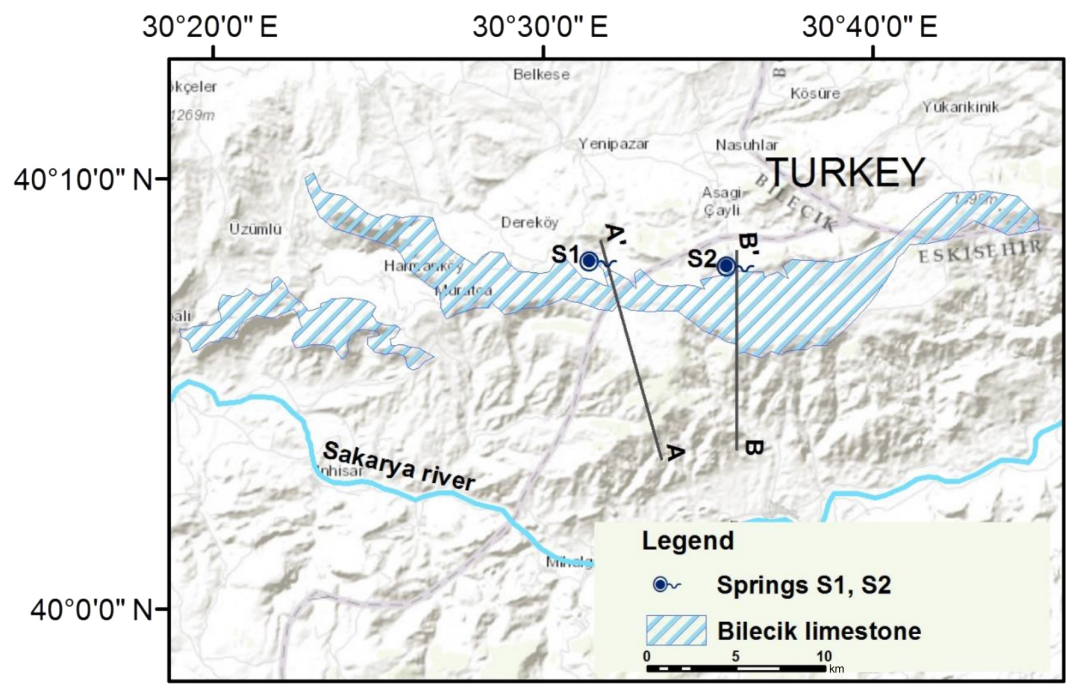

(a)

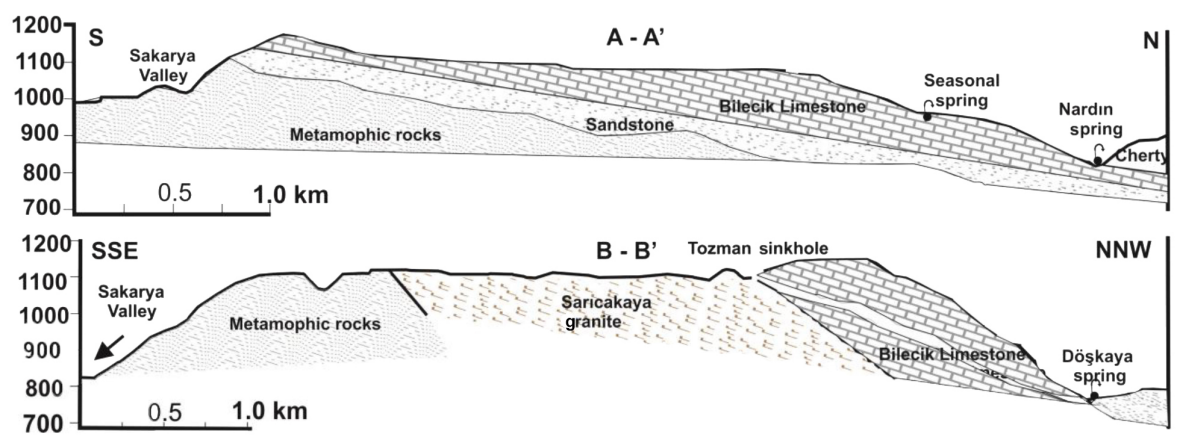

(b)

Figure 2. (a) Location map of Bilecik limestone (Jkb), (b) the geological cross section of Döskaya (S1) and Nardin (S2) springs (modified by Aydin et al., 2013).

The second group of springs is located in Çifteler and Günyüzü subbasins within Sakarya basin, SivrihisarEskişehir (Fig. 3). Sakarbasi and Kaymaz springs (S3, S4) were studied by Guner and Guner (2002), who determined little or no change in the in situ measurements during three seasons of sampling. The reservoir rock of Sakarbasi springs (S3; Sadıroğlu, Eminekin, Başkurt, Ilicabasi and Pınarbaşı) are composed of marble. This is named the Gökçeyayla formation, which is primarily shelf-type carbonate that is deposited during the Triassic-Upper Cretaceous. Dolomitic limestone is dominant in the lower section of the unit, while the upper section is mostly chert limestone (Gunay, 2006). The total groundwater discharge $\left(233 \times 10^{6} \mathrm{~m}^{3} \mathrm{yr}^{-1}\right)$ and pumped water $\left(49 \times 10^{6} \mathrm{~m}^{3} \mathrm{yr}^{-1}\right)$ in this aquifer is $282 \times 10^{6} \mathrm{~m}^{3} \mathrm{yr}^{-1}$. Gunay (2006) showed that recharge into this aquifer $\left(47 \times 10^{6} \mathrm{~m}^{3} \mathrm{yr}^{-1}\right)$ is much less than the discharge and explained that the deficit between the discharge and recharge is balanced with water coming from the neighbouring basins.
Günyüzü springs (S5-S10), located in Sakarya basin, were studied by Demiroglu (2008) (Fig. 3). Paleozoic marble, which is the main reservoir rock for hot and cold water, is bordered by impermeable diabase dykes at the sides and by impermeable granites and schists. Marble, at the top of the metamorphic series, at higher elevations of the basin, represents the upper part of the aquifer system. The S9 (Çukurçeşme) spring recharges, circulates and discharges from this system. This shallow circulation of water has laminar flow conditions (Demiroglu, 2008). Other shallow circulating waters (S5, Babadat and S6, Nasrettin Hoca) mostly recharge from the marble but discharge from Neogene units. Marble at the bottom of the basin with faults recharges and stores deep circulating water, where fracture permeability and diffuse infiltration (laminar flow conditions) control groundwater flow (S7, Çardak Hamami, S8, Subaş1 and $\mathrm{S} 10$, Yeniçıkrı). This deep circulating water discharges from Neogene units as well. However, partly developed conduit permeability and point infiltration from old karstic structures (sinkholes), fractures and joints in the marble reveal 


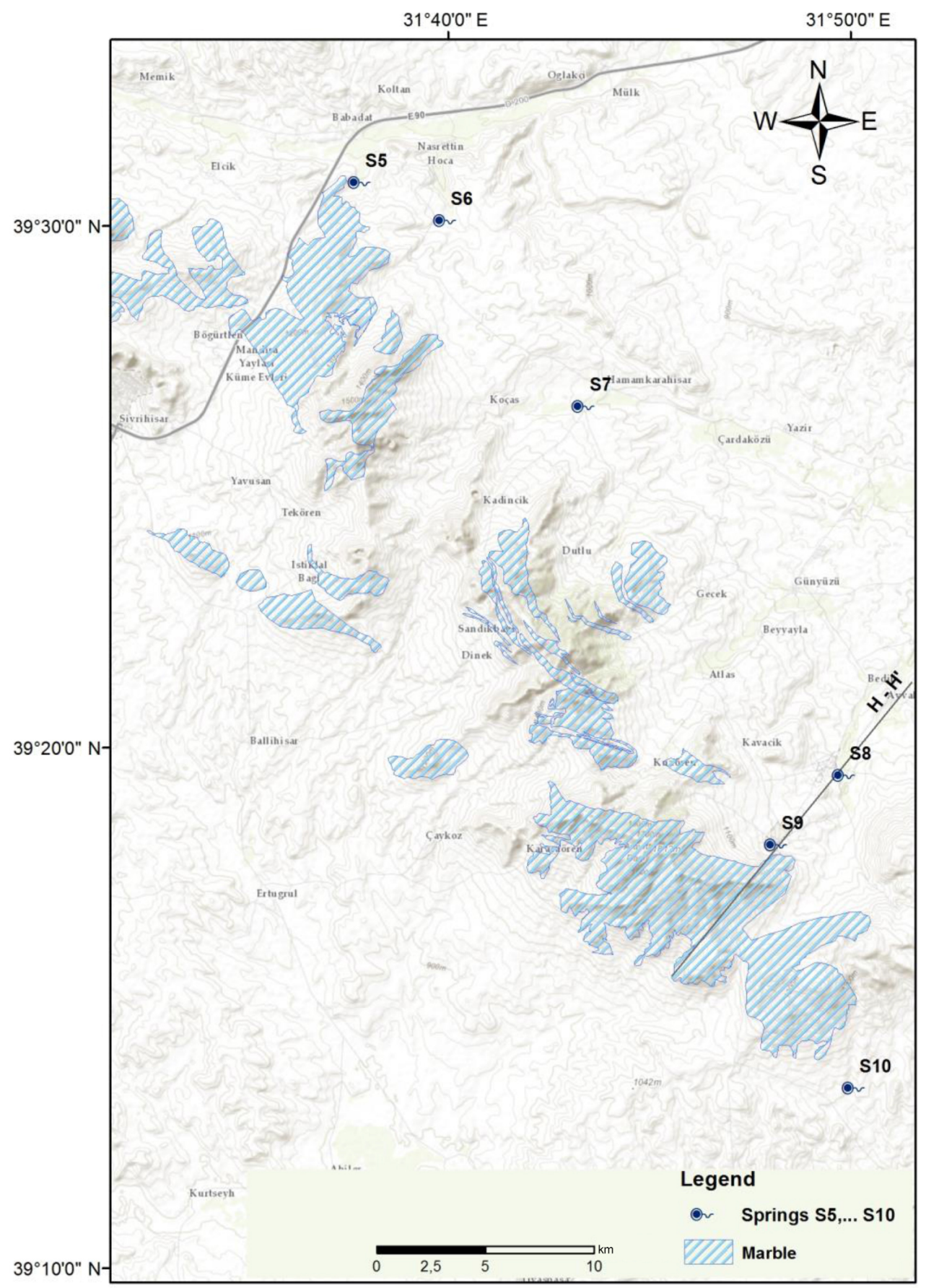

(a)

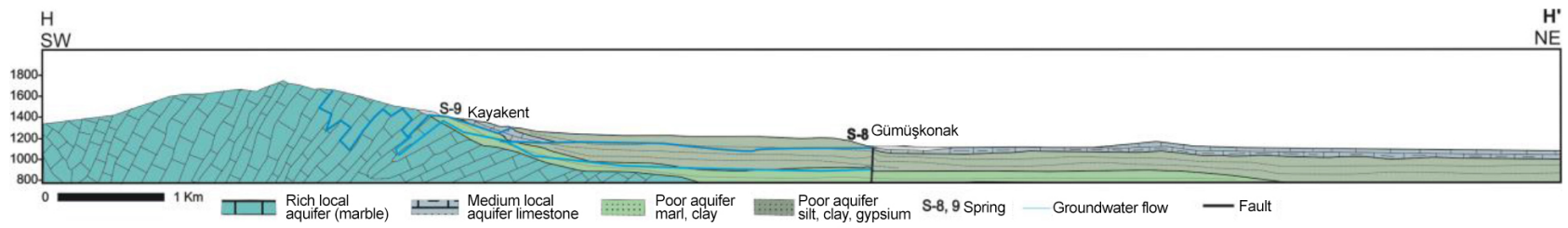

(b)

Figure 3. (a) Location map of Günyüzü marble, (b) the geological cross section of Günyüzü springs (Demiroglu, 2008). 
a turbulent regime in the vadose zone (Demiroglu, 2008). The groundwater total recharge and discharge were calculated as $30 \times 10^{6}$ and $32 \times 10^{6} \mathrm{~m}^{3} \mathrm{yr}^{-1}$, respectively, in the Günyüzü basin. The difference between the recharge and discharge for this particular basin cannot be explained by the recharge from neighbouring basins because of the impermeable aquifer boundary conditions. The most likely reason is the partly developed karstic structure and fast percolation (Demiroglu et al., 2011).

Measurements, observations and calculations given for the above examples show that discharge from aquifers is always higher than the recharge into the aquifer. The difference is usually assumed to be balanced by contribution of neighbouring subbasins. However, this is not the only way to explain the higher recharge. A more important reason, particularly in karst aquifers dominated by point infiltration, is the fast response of the aquifer to heavy rainfall that is expected to become more frequent in the future. This can be linked to the climate change, for which spring discharge is found to be a robust indicator (Fiorillo et al., 2015b).

The third group of springs is located in the Lake District (S10-S20 and Sütçüler springs) (Fig. 4). Mesozoic limestone is the most common unit around the lake, both autochthonous and allochthonous in origin. The allochthonous limestone makes up the major part of the Lycian Nappes. Middle-Upper Triassic dolomitic limestone, containing different lithofacies from thin layers to medium thick bedded levels, is the oldest part of the Mesozoic series. JurassicCretaceous limestone contains marine sediments from a deep to shallow marine environment. Thinly bedded chert micritic levels are also observed. Allochthonous nappes thrust over their autochthonous units in the form of tectonic slices. The autochthonous limestone is situated to the southeast of the Lycian overthrusted front. Slices show the ophiolitic melange feature at the bottom of this structure (Ekmekçi, 2005; Davraz et al., 2008). Important springs are located mostly along the tectonic contact between overthrusted limestone formations and impervious hydrogeological barriers (Gunay et al., 2015).

Kirkgozler springs (S19, S20) are very important for the Antalya region in the southwest of Turkey in supplying drinking water and for irrigation. They discharge from the boundary between the autochthonous limestone of the Beydağlari mountains and the impermeable ophiolite rock (Fig. 4) located at $300 \mathrm{~m}$ altitude. They are characterized by a highly regulated flow regime (Ozyurt, 2008).

Also a historical spring, Sagalassos (S18) exists in the Lake District and discharges from the deeply fractured allochthonous Cretaceous limestone. Sagalassos settlements from Roman times, with different types of infrastructures for the collection, transport and distribution of water, are worthy of being reevaluated.

Other examples in the Lake District are Sütçüler small springs. There are no regular yield and water chemistry measurements for these springs (Fig. 5). Sütçüler, a town located on the allochthonous limestone, faced flood disasters in November 1995 and October 2011. The Sütçüler small springs are activated by a sudden rise in groundwater. Here, heavy rainfall is combined with the capability of the karst system. During karst flash floods, a sudden rise in the groundwater level occurs, which causes the appearance of numerous, unexpected, abundant and temporary karst springs (Bonacci et al., 2006). The area was studied by Karaguzel and Akinci (1998) after flooding. The ophiolite complex consists of ultrabasic and sedimentary rock at the base, with the Jurassic-Cretaceous carbonate mass spread over a wide area and overlapping the ophiolitic rock. Erenler Mountain, located in the north of Sütçüler, is composed of limestone and has developed karstic structures (sinkholes, dolines) on the ophiolite complex. Plio-Quaternary travertine is exposed in the town; sand, gravel and block-size debris pile up at the base of steep slopes (Fig. 5). The town centre is mainly founded on the travertine and ophiolite complex. There is no permanent surface water flowing in the region. Springs discharge from the limestone-ophiolite contact.

\section{Materials and methods}

Representative and organized sampling of springs in Günyüzü basin, Eskişehir, Turkey, indicated that karst groundwater characteristics could be defined and used for the classification of karst aquifers regarding their contribution in generating flash floods (Demiroglu, 2008). In this manner, data related to the study area as listed in Table 1 were compiled from previous studies (Atilla, 1996; Aydin, 2005; Demiroglu, 2008) and from State Hydraulic Works, DSI of Turkey. It can be followed from Table 2 that some springs (S3, S9, S10) recharge, circulate and discharge from Paleozoic marble, some (S1, S2, S4, S15, S16, S17, S18, S19, S20) from Mesozoic limestone, while others (S4, S5, S6, S7, S8) recharge and circulate in marble, and circulate and discharge from Neogene limestone and clastics.

In situ groundwater hydrochemical measurements are important to identify the origin of groundwater and flow regimes, especially in karst regions. Shuster and White (1971) recorded that some springs have no seasonal fluctuations in their temperature and total hardness, while others show continuous seasonal fluctuation in spite of the fact that all springs are in similar geological environments. The fluctuations have been reduced to a single number for each spring by calculating the coefficient of variation (CV) of the total hardness. Further, the measure of electrical conductivity (EC) has widely been used instead of hardness to classify karst springs as a useful and practical tool (White, 2002). However, aquifers are combinations of diffuse and conduit systems (or slow and fast flows) due to the triple permeability (matrix, fracture and conduit). Lower variability in hydrochemical characteristics can be observed not only in diffuse flow but also in conduit flow (Atkinson, 1977). 

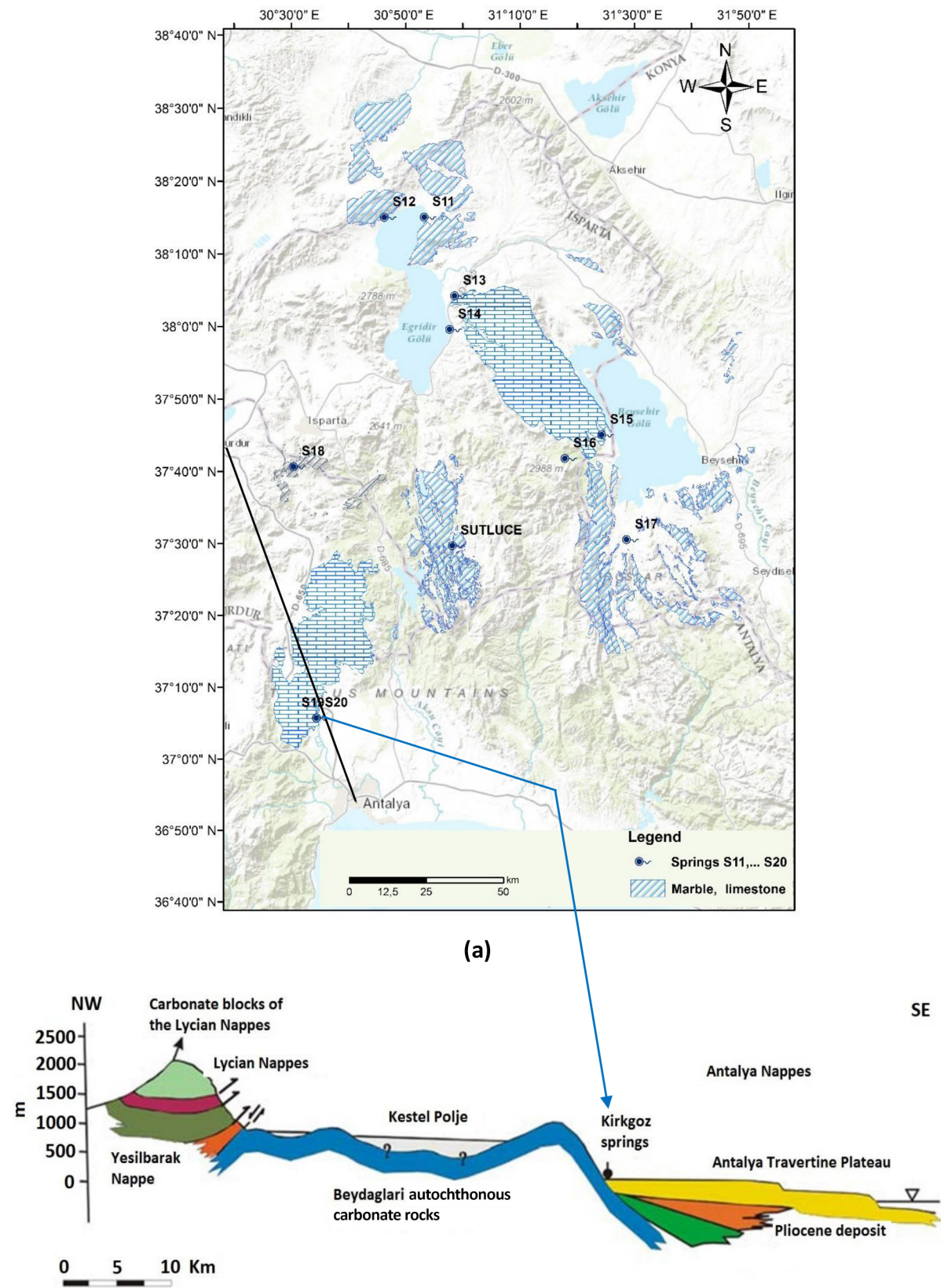

(b)

Figure 4. (a) Location map of Lake District marble and limestone, (b) the geological cross section of the Kirkgoz karst springs, southern Turkey (Ekmekçi, 2005).

This means that the aquifer either has a diffuse-infiltrationdominated recharge or it is a conduit flow aquifer with large storage, showing almost no response to allogenic recharge. Massei et al. (2007) suggested that the different modalities of the specific conductance frequency distributions of karst spring discharge reflect the movement of geochemically distinct masses of water through the aquifer and that the mean specific conductance of an individual water mass, or type, depends on its origin and residence time.

In this study, physico-chemical analysis of ground water is used for the classification of aquifers. The relationship between electrical conductivity (EC), temperature $(T)$ and dissolved oxygen (DO) indicates the existence of groups of water with different origins (Mazor, 1991). Aquifers are classified as deep and shallow circulating water based on the fact 


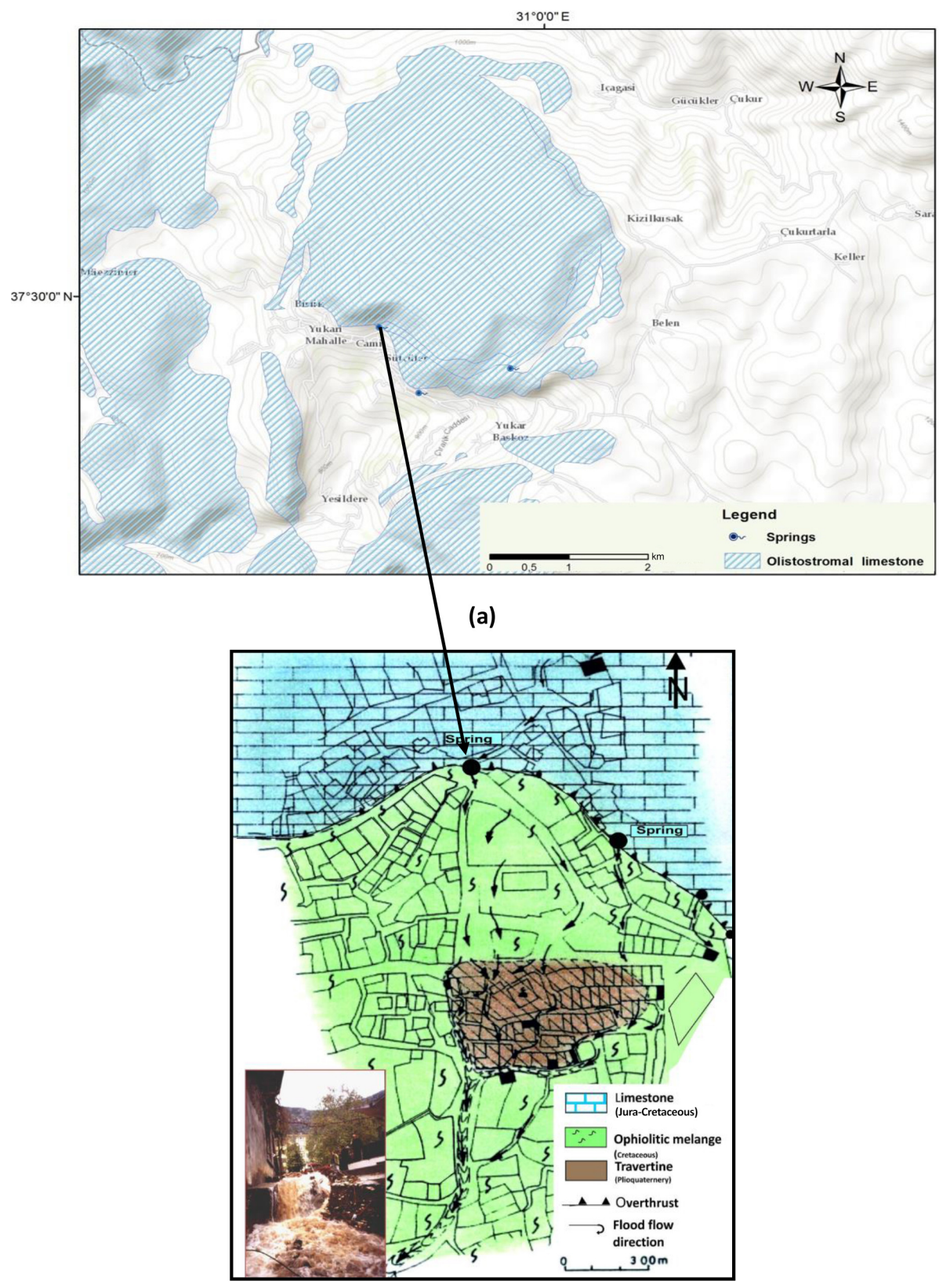

(b)

Figure 5. (a) Location map of Sütçüler limestone, (b) a view of the flood in 1995 and flooding paths on a geological map of Sütçüler settlements (Karaguzel and Akinci, 1998).

that groundwater samples with high EC, high $T$ and low DO represent the deep circulating water, while low EC, low $T$ and high DO represent the shallow circulating water. In this study, hydrogeological characteristics of basins (topography, hydrogeological layers, physical boundary, recharge, discharge and storage capacity of aquifer), circulating type (deep and shallow) and residence time were defined first for the classification of aquifers. Measurements in wet and dry seasons and discharge rates in springs were then compared in order to support and explain aquifer characteristics. Discharge variability can also be used to estimate regional hydrogeological processes and hydraulic properties of aquifers. Springs with high discharge variability can indicate a high degree of transport properties of the aquifer and the quick response of the system to recharge. The simplest measure of spring discharge variability is given by the ratio of the maximum and minimum discharges $\left(Q_{\max } / Q_{\min }\right)$. A value of discharge variability higher than 10 shows highly vari- 
Table 2. Hydrogeological data of springs.

\begin{tabular}{|c|c|c|c|c|}
\hline No. & $\begin{array}{l}\text { Aquifer } \\
\text { lithology }\end{array}$ & $\begin{array}{l}\text { Discharge } \\
\text { lithology }\end{array}$ & $\begin{array}{l}\text { Circulating } \\
\text { type }\end{array}$ & $\begin{array}{l}\text { Residence } \\
\text { time }\end{array}$ \\
\hline S1 & $\begin{array}{l}\text { Jurassic } \\
\text { limestone }\end{array}$ & $\begin{array}{l}\text { Jurassic } \\
\text { limestone }\end{array}$ & Shallow & Short \\
\hline $\mathrm{S} 2$ & $\begin{array}{l}\text { Jurassic } \\
\text { limestone }\end{array}$ & $\begin{array}{l}\text { Jurassic } \\
\text { limestone }\end{array}$ & Shallow & Short \\
\hline S3 & $\begin{array}{l}\text { Paleozoic } \\
\text { marble }\end{array}$ & $\begin{array}{l}\text { Paleozoic } \\
\text { marble }\end{array}$ & Deep & Long \\
\hline S4 & $\begin{array}{l}\text { Cretaceous } \\
\text { limestone }\end{array}$ & $\begin{array}{l}\text { Neogene } \\
\text { limestone }\end{array}$ & Shallow & Long \\
\hline S5 & $\begin{array}{l}\text { Paleozoic } \\
\text { marble }\end{array}$ & $\begin{array}{l}\text { Neogene } \\
\text { sediments }\end{array}$ & Shallow & Short \\
\hline S6 & $\begin{array}{l}\text { Paleozoic } \\
\text { marble }\end{array}$ & $\begin{array}{l}\text { Neogene } \\
\text { limestone }\end{array}$ & Shallow & Short \\
\hline S7 & $\begin{array}{l}\text { Paleozoic } \\
\text { marble }\end{array}$ & $\begin{array}{l}\text { Neogene } \\
\text { sediments }\end{array}$ & Deep & Long \\
\hline S8 & $\begin{array}{l}\text { Paleozoic } \\
\text { marble }\end{array}$ & $\begin{array}{l}\text { Neogene } \\
\text { limestone }\end{array}$ & Deep & Long \\
\hline S9 & $\begin{array}{l}\text { Paleozoic } \\
\text { marble }\end{array}$ & $\begin{array}{l}\text { Paleozoic } \\
\text { marble }\end{array}$ & Shallow & Short \\
\hline S10 & $\begin{array}{l}\text { Paleozoic } \\
\text { marble }\end{array}$ & $\begin{array}{l}\text { Paleozoic } \\
\text { marble }\end{array}$ & Shallow & Long \\
\hline $\mathrm{S} 11$ & $\begin{array}{l}\text { Mesozoic } \\
\text { limestone }\end{array}$ & $\begin{array}{l}\text { Miocene } \\
\text { sediments }\end{array}$ & Shallow & Short \\
\hline $\mathrm{S} 12$ & $\begin{array}{l}\text { Mesozoic } \\
\text { limestone }\end{array}$ & $\begin{array}{l}\text { Miocene } \\
\text { sediments }\end{array}$ & Shallow & Short \\
\hline S13 & $\begin{array}{l}\text { Mesozoic } \\
\text { limestone }\end{array}$ & $\begin{array}{l}\text { Miocene } \\
\text { sediments }\end{array}$ & Shallow & Long \\
\hline S14 & $\begin{array}{l}\text { Mesozoic } \\
\text { limestone }\end{array}$ & $\begin{array}{l}\text { Mesozoic } \\
\text { melange }\end{array}$ & Shallow & Long \\
\hline S15 & $\begin{array}{l}\text { Mesozoic } \\
\text { limestone }\end{array}$ & $\begin{array}{l}\text { Mesozoic } \\
\text { limestone }\end{array}$ & Shallow & Long \\
\hline S16 & $\begin{array}{l}\text { Mesozoic } \\
\text { limestone }\end{array}$ & $\begin{array}{l}\text { Mesozoic } \\
\text { limestone }\end{array}$ & Shallow & Short \\
\hline S17 & $\begin{array}{l}\text { Mesozoic } \\
\text { limestone }\end{array}$ & $\begin{array}{l}\text { Mesozoic } \\
\text { limestone }\end{array}$ & Shallow & Long \\
\hline S18 & $\begin{array}{l}\text { Cretaceous } \\
\text { limestone }\end{array}$ & $\begin{array}{l}\text { Cretaceous } \\
\text { limestone }\end{array}$ & Shallow & Short \\
\hline S19 & $\begin{array}{l}\text { Jurassic } \\
\text { limestone }\end{array}$ & $\begin{array}{l}\text { Jurassic } \\
\text { limestone }\end{array}$ & Shallow & Long \\
\hline $\mathrm{S} 20$ & $\begin{array}{l}\text { Jurassic } \\
\text { limestone }\end{array}$ & $\begin{array}{l}\text { Jurassic } \\
\text { limestone }\end{array}$ & Shallow & Long \\
\hline
\end{tabular}

able springs, while a value lower than 2 points to a constant or steady spring (Stevanovic, 2015). High discharge variability $\left(Q_{\max } / Q_{\min }\right)$ and a rapid change in temperature and chemical composition reveal turbulence flow conditions in developed karstic structures with low storages (Aydin, 2005; Demiroglu, 2008). Low variations of the measurements in both wet and dry seasons point to fracture and matrix permeability dominated by diffused controlled groundwater flow with low or high storage, and conduit permeability with high storage. In this study, aquifers are investigated by using this approach to classify them as springs with or without a fast response to heavy rainfall.

\section{Results and discussions}

Data compiled for the study area were analysed based on the proposed approach for the three groups of springs as follows.

As the signature of karst aquifers, in situ measurements in wet and dry seasons are first separated in order to evaluate the seasonal variability in water geochemistry and dilution effect. As demonstrated in Table 3, the groundwater has $\mathrm{pH}$ values ranging from 6.38 to 8.9 , temperature from 5 to $34.8^{\circ} \mathrm{C}$, EC values from 140 to $998 \mu \mathrm{sm}^{-1}$, DO from 2.21 to $11.00 \mathrm{mg} \mathrm{L}^{-1}$ and $\mathrm{Ca}$ from 1.21 to $7.44 \mathrm{meq} \mathrm{L}^{-1}$. Water with high EC, high $T$ and low DO was classified as the deep circulating water, while water with low EC, low $T$ and high DO was considered to be within the shallow circulating water group (Table 3), although the DO data were not available for some springs.

For the first group of springs (S1 and S2 in Bilecik area), 2 years of in situ measurements in dry and wet seasons are given in Table 3, from which fluctuations in the physicochemical data can be noticed. Discharge rates and the CV of physico-chemical data are given in Table 4. Change in discharge is within 2 orders of magnitudes ranging from 0 to almost $400 \mathrm{~L} \mathrm{~s}^{-1}$ of maximum discharge rate for S1, and from $1.5 \mathrm{~L} \mathrm{~s}^{-1}$ to more than $200 \mathrm{~L} \mathrm{~s}^{-1}$ for $\mathrm{S} 2$. When geological cross sections of S1 and S2 are considered, their low-storage structure and high hydraulic gradient are easily seen. It is further seen that $\mathrm{S} 1$ has a steeper hydraulic gradient than S2. This is in agreement with Aydin (2005), who concluded that these aquifers have a conduit permeability with low storage dominantly controlled by turbulent groundwater flow based on the hydrogeological and hydrogeochemical analysis. The low storage, combined with the high transmissivity, does not allow the spring to retain water; most of the recharge is not retained by the karst system. Therefore, a rapid flow is generated to the springs, which can be considered as evidence to support the aquifer being located in a flash-flood-prone area.

EC measurements show that variations in physicochemical data depend not only on circulation depth and residence time but also on lithology. For example, springs S3 and S8 (Table 3) nearly have the same temperature and DO (26.6-30 $\left.{ }^{\circ} \mathrm{C} / 4.36-4.81 \mathrm{mg} \mathrm{L}^{-1}\right)$, which represent approxi- 
Table 3. Physico-chemical data of springs.

\begin{tabular}{|c|c|c|c|c|c|c|c|c|c|c|c|}
\hline \multirow[t]{2}{*}{ Group } & \multirow[t]{2}{*}{ Spring } & \multicolumn{5}{|c|}{ Dry season } & \multicolumn{5}{|c|}{ Wet season } \\
\hline & & $\begin{array}{c}T \\
\left({ }^{\circ} \mathrm{C}\right)\end{array}$ & $\mathrm{pH}$ & $\begin{array}{c}\mathrm{EC} \\
\left(\mu \mathrm{cm}^{-1}\right)\end{array}$ & $\begin{array}{l}\mathrm{DO} \\
\left(\mathrm{mg} \mathrm{L}^{-1}\right)\end{array}$ & $\begin{array}{l}\mathrm{Ca} \\
\left(\mathrm{meq} \mathrm{L}^{-1}\right)\end{array}$ & $\begin{array}{r}T \\
\left({ }^{\circ} \mathrm{C}\right)\end{array}$ & $\mathrm{pH}$ & $\begin{array}{c}\mathrm{EC} \\
\left(\mu \mathrm{cm}^{-1}\right)\end{array}$ & $\begin{array}{l}\mathrm{DO} \\
\left(\mathrm{mg} \mathrm{L}^{-1}\right)\end{array}$ & $\begin{array}{l}\mathrm{Ca} \\
\left(\operatorname{meq} \mathrm{L}^{-1}\right)\end{array}$ \\
\hline \multirow{2}{*}{ I } & $\mathrm{S} 1$ & 11.90 & 7.23 & 512 & 10.14 & 8.40 & 5.00 & 6.84 & 160 & 11.00 & 2.20 \\
\hline & $\mathrm{S} 2$ & 22.70 & 6.97 & 687 & 7.77 & 7.14 & 13.70 & 6.38 & 483 & 7.12 & 5.59 \\
\hline \multirow{8}{*}{ II } & S3 & 26.60 & 7.37 & 398 & 4.36 & 4.90 & 27.50 & 7.57 & 350 & ND & ND \\
\hline & $\mathrm{S} 4$ & 23.00 & 7.28 & 820 & ND & ND & 18.70 & 7.28 & 750 & ND & ND \\
\hline & S5 & 20.50 & 6.92 & 405 & 8.06 & 3.11 & 20.46 & 7.09 & 416 & 7.75 & 3.18 \\
\hline & S6 & 22.75 & 7.17 & 403 & 7.68 & 3.21 & 22.18 & 7.16 & 405 & 7.36 & 3.12 \\
\hline & S7 & 34.75 & 6.93 & 935 & 2.89 & 3.89 & 34.44 & 7.02 & 959 & 2.21 & 4.70 \\
\hline & S8 & 30.00 & 6.94 & 778 & 4.81 & 4.65 & 29.92 & 6.86 & 798 & 4.46 & 4.69 \\
\hline & S9 & 14.02 & 7.15 & 346 & 9.11 & 2.60 & 13.49 & 7.21 & 331 & 8.89 & 2.54 \\
\hline & $\mathrm{S} 10$ & 22.82 & 7.08 & 590 & 7.49 & 3.58 & 22.91 & 6.96 & 603 & ND & 3.89 \\
\hline \multirow{10}{*}{ III } & $\mathrm{S} 11$ & 14.00 & 7.6 & 600 & ND & 2.66 & 12.70 & 7.8 & 500 & ND & 2.54 \\
\hline & $\mathrm{S} 12$ & 17.20 & 7.7 & 630 & ND & 3.21 & 11.20 & 8.2 & 480 & ND & 2.47 \\
\hline & S13 & 13.00 & 7.8 & 443 & ND & 4.19 & 13.80 & 7.7 & 586 & ND & 2.63 \\
\hline & S14 & 22.70 & 8.4 & 787 & ND & 2.68 & 11.40 & 8.4 & 410 & ND & ND \\
\hline & S15 & 18.70 & 8.9 & 381 & ND & 4.90 & 11.00 & 8.2 & 357 & ND & 1.21 \\
\hline & S16 & 6.80 & 8.9 & 140 & ND & 1.50 & 7.20 & 8.8 & 154 & ND & ND \\
\hline & S17 & 10.40 & 8.4 & 300 & ND & 3.05 & 11.00 & 8.5 & 320 & ND & ND \\
\hline & S18 & 16.60 & 8.8 & 191 & ND & 2.60 & 10.50 & 8.4 & 214 & ND & 1.95 \\
\hline & S19 & 16.70 & 6.6 & 988 & 4.2 & 7.80 & 16.70 & 7.0 & 969 & 6.0 & 7.44 \\
\hline & S20 & 16.80 & 6.5 & 998 & 4.4 & 7.80 & 17.90 & 7.1 & 936 & 8.9 & 7.14 \\
\hline
\end{tabular}

mately the same circulation depth and residence time. However, the EC value differences $\left(398,778 \mu \mathrm{sm}^{-1}\right)$ stem from lithology. Spring S3 recharges, circulates and discharges from Paleozoic marble, whereas spring S8 recharges and circulates in Paleozoic marble, then circulates and discharges from Neogene limestone and clastics. In this respect, the chemical signature of karst aquifer mainly depends on lithology, residence time and hydrological conditions. The clear effect of residence time can be seen when EC values of springs that recharge and discharge in the same age carbonates (S9, S10, S15, S16, S17) are considered.

Average $\mathrm{Ca}$ and $\mathrm{EC}$ were measured to be $3 \mathrm{meq} \mathrm{L}^{-1}$ and $384 \mu \mathrm{s} \mathrm{cm}^{-1}$, respectively, in the shallow circulating water discharges from Paleozoic marble in the Günyüzü basin (S5, S6, S9), and $6.4 \mathrm{meqL}^{-1}$ and $596 \mu \mathrm{sm}^{-1}$ in the S3 discharges from the Bilecik Jurassic limestone (Aydin, 2005). These springs have a short residence time. In the springs with a long residence time, average $\mathrm{Ca}$ and $\mathrm{EC}$ are, respectively, measured to be $3.58 \mathrm{meq} \mathrm{L}^{-1}$ and $590 \mu \mathrm{sm}^{-1}$ for the Yeniçıkrı spring, which discharges again from Paleozoic marble in the Günyüzü basin. They are $7.5 \mathrm{meq} \mathrm{L}^{-1}$ and $988 \mu \mathrm{sm}^{-1}$ in the Kirkgozler spring from Antalya Jurassic limestone (Atilla, 1996). The difference between $\mathrm{Ca}$ and $\mathrm{EC}$ values in marble and limestone basins can be due to marble being less soluble than limestone.

Table 3 shows that the second group of springs (S3-S10) displays nearly constant temperature, low variations for the

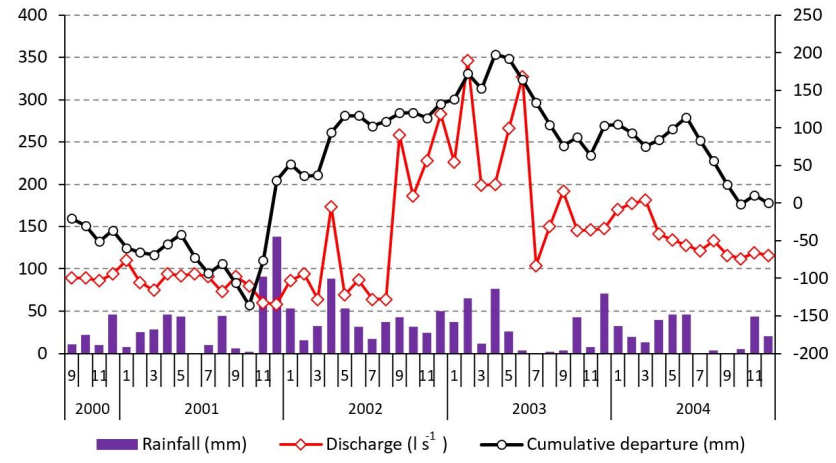

Figure 6. Hyetograph, hydrograph and cumulative departure of the Subaş1 spring (S8) (vertical axis on the left is used for both rainfall and discharge, vertical axis on the right for cumulative departure only).

measurements both in dry and wet seasons and low discharge rates $\left(Q_{\max } / Q_{\min }\right)$. Of these springs, $\mathrm{S} 3, \mathrm{~S} 8$ and $\mathrm{S} 10$ display higher coefficients of variation for discharge (Table 4). The Subaş1 spring (S8) hydrograph given in Fig. 6 as an example reflects a correlation between cumulative precipitation departure and discharge, unlike the monthly precipitation which does not replace such a correlation. Annual precipitation could influence the discharge of the following hydrological year (Fiorillo, 2009; Fiorillo et al., 2015b). This memory effect in aquifers controlled by diffusive infiltration is longer 
Table 4. Discharge characteristics of springs and variations in physico-chemical data.

\begin{tabular}{lllllll}
\hline No. & $\begin{array}{l}Q_{\max } \\
\left(\mathrm{L} \mathrm{s}^{-1}\right)\end{array}$ & $\begin{array}{l}Q_{\min } \\
\left(\mathrm{L} \mathrm{s}^{-1}\right)\end{array}$ & $\begin{array}{l}Q_{\max } / \\
Q_{\min }\end{array}$ & $\mathrm{CV}_{Q}$ & $\mathrm{CV}_{\mathrm{EC}}$ & $\mathrm{CV}_{\mathrm{Ca}}$ \\
\hline S1 & 395.8 & 0 & $\infty$ & 74.8 & 38.58 & 36.6 \\
S2 & 208.9 & 1.5 & 139.3 & 148.8 & 10.81 & 7.3 \\
S3 & 273 & 36 & 7.5 & 33 & $\mathrm{ND}$ & $\mathrm{ND}$ \\
S4 & 2490 & 1447 & 1.72 & 13.9 & $\mathrm{ND}$ & $\mathrm{ND}$ \\
S5 & 100 & 68 & 1.47 & 22.6 & 4.96 & 6.01 \\
S6 & 219 & 152 & 1.44 & 13.48 & 3.96 & 6.63 \\
S7 & 140 & 39 & 3.58 & 29.39 & 12.3 & 4.2 \\
S8 & 181 & 112 & 1.61 & 50.6 & 11.9 & 8.9 \\
S10 & 108 & 49 & 2.2 & 36.4 & 10.3 & 8.04 \\
S16 & 4078 & 4 & 1019.5 & 103 & $\mathrm{ND}$ & $\mathrm{ND}$ \\
S20 & 22000 & 10000 & 2.2 & 12 & 30 & 31 \\
\hline
\end{tabular}

than that in the point-infiltration-controlled aquifers. However, it is observed in Fig. 6 that the Subaş1 spring discharge of $64 \mathrm{~L} \mathrm{~s}^{-1}$ in March 2002 suddenly rose to $173 \mathrm{~L} \mathrm{~s}^{-1}$ in April after heavy precipitation of $88.3 \mathrm{~mm}$ in this particular month which is more than twice compared to the long-term (1925-2005) average $(43.98 \mathrm{~mm})$ of the total precipitation. This shows that the vadose zone (developed fossil karstic structure) is activated after heavy rainfall to carry the surge to surface water and to deep aquifers (Demiroglu, 2008). Therefore, the Subaşı spring (S8) is classified as having high response capability to heavy rainfall at very high groundwater levels.

As in the example of Subaşı spring (S8), aquifers dominantly controlled by diffused groundwater flow can also cause inter-catchment overflow and redistribution of catchment areas at very high groundwater levels because of fossil and inactive conduits and spring activation in vadose zone (Bonacci et al., 2006). It is directly linked to the structure and hydraulic properties of karst aquifers (Fleury et al., 2013). Therefore, karst structures should be taken into account as a component of the hydrological budget of the watershed to avoid the unexpected, uncalculated additional water coming from neighbouring watersheds. For example, Eris and Wittenberg (2015) showed that water transfer between neighbouring karstic watersheds in Mediterranean Turkey was considerable. Furthermore, Parise (2003) and Gutierrez et al. (2014) emphasized the influence to karst floods by clogged swallow holes, new sinkholes consequential to high rainfall rates and alterations to the natural system of caves.

Data of the first and second groups of springs in Bilecik and Eskişehir can be considered enough for a reliable prediction of aquifer properties. However, this is not the case for the Lake District springs, except for the well-studied Kirkgozler springs. Therefore, the Lake District needs further organized sampling. The Kirkgozler springs (S19, S20), the historical Sagalassos spring (S18) and Sütçüler springs in the Lake District are discussed below. It can be said that Lake Dis-

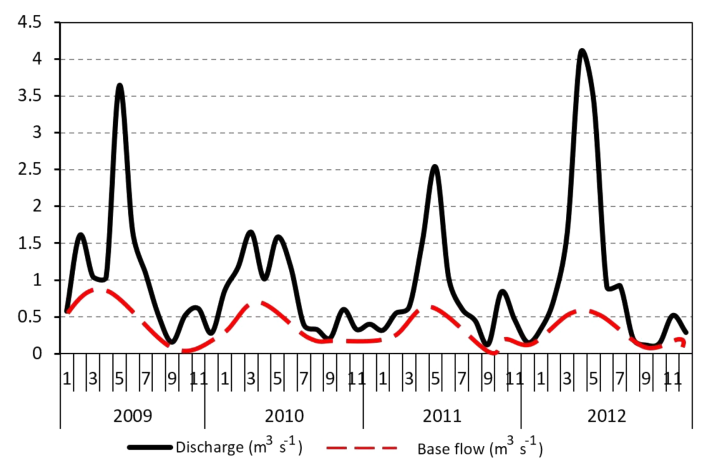

(a)

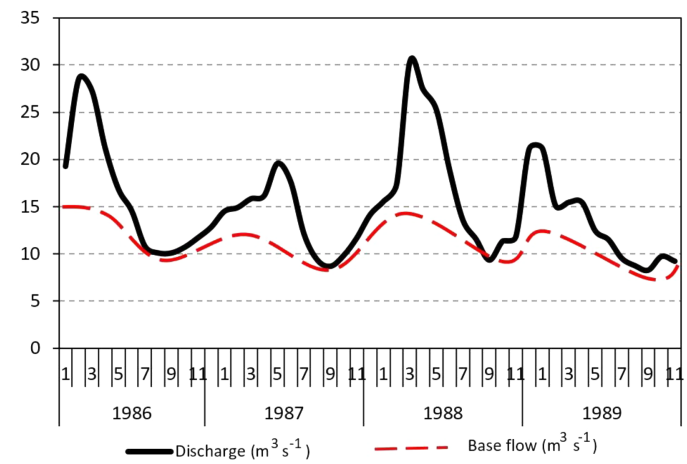

(b)

Figure 7. Hydrograph for fast flow springs: (a) Pınargözü spring (conduit-dominated poor base flow), (b) Kirkgozler spring (conduit-dominated large base flow).

trict aquifers are dominated by conduit permeability with low storage, except for S17 and Kirkgozler springs (S19, S20) when the dry and wet season in situ measurements of the springs are considered (Tables 3 and 4). Temperature changes in S13 slightly. However, EC values are higher in the wet season than in the dry season because the aquifer is recharged by Miocene sediments. For this reason, additional data are required for spring S13 to classify it as either conduit- or diffuse-flow-dominated. Another aquifer, S17, with developed karst structures, shows slight differences in $T$ and EC. It can therefore be classified as a conduit-flow-dominated aquifer with high storage.

Another exceptional example is the Pınargözü spring (S16). Its discharge has a high variation that can be tripled or sharply lowered by one-third. For example, the discharge $887 \mathrm{~L} \mathrm{~s}^{-1}$ in 27 March 2006 suddenly increased to $3255 \mathrm{~L} \mathrm{~s}^{-1}$ in 12 April 2006 and $3438 \mathrm{~L} \mathrm{~s}^{-1}$ in 14 May 2012; and it suddenly declined to $906 \mathrm{~L} \mathrm{~s}^{-1}$ in 11 June 2012 . The hydrograph exhibits strikingly steep, short duration with high amplitudes (Fig. 7). The transformation of rainfall into spring discharge is very rapid. After a rainfall event, some of these springs even dry up. Conversely, the process can be rather slow and long-lasting, due to the storage potential and retardation capacity of underground voids (Stevanovic, 
2015). Therefore, the major flow type of $\mathrm{S} 16$ is considered to be turbulent or quick flow, showing that the spring is located in a flash-flood-prone area. Kirkgozler springs (S19, S20) are the largest springs in the Lake District. A discharge hydrograph in the Kirkgozler springs is given to demonstrate the difference between two conduit-flow-dominated springs (Fig. 7). Kirkgozler springs (S19, S20), which have a large base flow, show the effects of wet and dry seasons, while the Pınargözü spring (S16) hydrograph markedly shows storm events.

The Sagalassos spring (S18) also shows rapid changes in measurements in dry and wet seasons (Table 3), which is a good example of a high response capability to heavy rainfall taking place in the ancient city. Surprisingly, natural flood risks were taken into account in Roman times in Sagalassos. Excavations indicate that large open areas were carefully designed into the urban infrastructure to collect and drain the natural floods, flushing down from the mountains, hence protecting the buildings from damage (UNESCO, 2009). Karst lands cannot be disregarded based on lessons learnt from ancient populations (Parise and Sammarco, 2015).

The most prominent effect of the climate change is that the number of days with excessive rainfall has been increasing in Turkey, and the amount of rain falling in heavy events is likely to increase and be more frequent (Aksoy et al., 2008). Despite this, there is a general lack of awareness of the impact of karstic springs on flooding although there have been several heavy rainfall events in the karstic southwest area of Turkey, such as flood events in Sütçüler (Karaguzel and Akinci, 1998). Being aware of the importance of heavy rainfall and flooding afterwards in the karst areas, the General Directorate of Combating Desertification and Erosion, established under the Ministry of Forestry and Water Affairs of the Republic of Turkey, conducted a project financed by the World Bank in 1999 to combat desertification and land degradation in the Sütçüler region. In this project, 2602 ha of erosion control and 490 ha of pasture improvement works were realized. Despite these measures, a flood occurred again on 25 December 2011 in the Sütçüler region. As considered in the ancient time similar to the Sagalassos case, for the safety of urban areas such as Sütçüler, urban drainage systems must be designed, taking karst springs into account. Additionally, hydrology and hydrogeology, two well-connected disciplines on flood events in karst regions of Turkey, must be included in flood control projects.

\section{Conclusions}

Based on analyses and discussions of the data compiled for the karst springs in the study area, the following concluding remarks can be derived.

1. An approach based on groundwater temperature, physico-chemical properties and discharge rates of springs, in addition to lithological and structural fea- tures, is used to determine the storage and flow conditions of the aquifer. This approach can also be employed for the identification of flood-prone areas in large regions, provided that representative and organized data sampling is available at least twice, in wet and dry seasons.

2. Recharge of karst aquifers dominated by conduit permeability increases with heavy rain, which is becoming more frequent with climate change.

3. Deeply fractured karst aquifers located on steeper parts of the land and bordered by impervious rock can transfer a considerable amount of water from different hydrological drainage basins to flood areas. It should be kept in mind that each karst aquifer is site-specific and has its own signature. In situ measurements and discharge rates ratio can give quick assessments and insights before a detailed analysis-based validation is performed.

4. For the safety of urban areas, drainage system designs should consider the impact of karst springs, as in ancient times.

5. Finally, to achieve more reliable estimates, the cooperation between hydrologists and hydrogeologists is important and needs to be emphasized.

Acknowledgements. The author would like to thank the reviewers and the editor for their constructive and courageous comments that improved the paper substantially. The manuscript has been edited in terms of its language by Darwin E. Fox, whom the author deeply thanks.

Edited by: M. Parise

Reviewed by: Y. Örgün and one anonymous referee

\section{References}

Aksoy, H., Unal, N. E., Alexandrov, V., Dakova, S., and Yoon, J.: Hydrometerological analysis of northwestern Turkey with links to climate change, Int. J. Climatol., 28, 1047-1060, doi:10.1002/joc.1599, 2008.

Aquilina, L., Ladouche, B., and Doerfliger, N.: Recharge processes in karstic systems investigated through the correlation of chemical and isotopic composition of rain and spring-waters, Appl. Geochem., 20, 2189-2206, doi:10.1016/j.apgeochem.2005.07.011, 2005.

Atilla, A. O.: Evaluation of hydrogeochemical data using multivariate statistical analysis techniques, MS Thesis, Hacettepe University, Institute of Science and Technology, Hacettepe, Ankara, p. $145,1996$.

Atkinson, T. C.: Diffuse flow and conduit flow in limestone terrain in the Mendip Hills, Somerset (Great Britain), J. Hydrol., 35, 93110, doi:10.1016/0022-1694(77)90079-8, 1977. 
Aydin, H.: Investigation of morphology-hydrogeology relations in Harmankoy-Beyyayla (Bilecik) karst system, PhD Thesis (in Turkish with English summary), Hacettepe University, Institute of Science and Technology, Hacettepe, Ankara, p. 206, 2005.

Aydin, H., Ekmekci, M., and Soylu, M. E.: Characterization and conceptualization of a relict karst aquifer (Bilecik, Turkey), Acta Carsologica, 42, 7-92, 2013.

Bacanli, H., Celik, S., Gorgec, H., and Deniz, A.: Meteorological analysis of the flood disaster that occurred in the western Marmara region at 7-9 September 2009, Proc. 5th Atmospheric Science Symposium, Istanbul, 451-460, 2011.

Bakalowicz, M.: Karst and karst groundwater resources in the Mediterranean, Environ. Earth Sci., 74, 5-14, doi:10.1007/s12665-015-4239-4, 2015.

Bonacci, O.: Monthly and annual effective infiltration coefficient in Dinaric karst: example of the Gradole karst spring catchment, Hydrolog. Sci. J., 46, 287-300, doi:10.1080/02626660109492822, 2001.

Bonacci, O., Ljubenkov, I., and Roje-Bonacci, T.: Karst flash floods: an example from the Dinaric karst (Croatia), Nat. Hazards Earth Syst. Sci., 6, 195-203, doi:10.5194/nhess-6-195-2006, 2006.

CCSP - US Climate Change Science Program: The effects of climate change on agriculture, land resources, water resources, and biodiversity in the United States, A Report by the US Climate Change Science Program and the Subcommittee on Global Change Research, edited by: Backlund, P., Janetos A., Schimel, D., et al., US Environmental Protection Agency, Washington, D.C., USA, p. 252, 2008.

Chicanoa, M. L., Bouamamaa, M., Vallejosb, A., and Boschb, A. P.: Factors which determine the hydrogeochemical behaviour of karstic springs. A case study from the Betic Cordilleras, Spain, Appl. Geochem., 16, 1179-1192, doi:10.1016/S08832927(01)00012-9, 2001.

Cossu, A., De Waele, J., and Di Gregorio, F.: Coastal karst geomorphosites at risk? A case study: the floods of 6-11 December 2004 in central-east Sardinia, Natural and Anthropogenic Hazards in Karst Areas: Recognition, Analysis, and Mitigation, Special Publication no. 279, Geological Society, London, 85-95, doi:10.1144/SP279.8, 2007.

Davraz, A., Karaguzel, R., Soyaslan, I., Sener, E., Seyman, F., and Sener, S.: Hydrogeology of karst aquifer systems in SW Turkey and an assessment of water quality and contamination problems, Environ. Geol., 58, 973-988, doi:10.1007/s00254-008-1577-5, 2008.

Demiroglu, M.: Hydrogeology and Hydrochemistry of EskişehirSivrihisar-Günyüzü Basin, PhD Thesis, Istanbul Technical University, Institute of Science and Technology, Istanbul, p. 197, 2008.

Demiroglu, M., Orgun, Y., and Yaltirak, C.: Hydrogeology and hydrogeochemistry of Gunyuzu semi-arid basin, Environ. Earth Sci., 64, 1433-1443, doi:10.1007/s12665-011-0967-2, 2011.

De Vries, J. J. and Simmers, I.: Groundwater recharge: an overview of processes and challenges, Hydrogeol. J., 10, 5-17, doi:10.1007/s10040-001-0171-7, 2002.

De Waele, J. and Parise, M.: Discussion on the article "Coastal and inland karst morphologies driven by sea level stands: a GIS based method for their evaluation" by Canora, F., Fidelibus, D., and Spilotro, G., Earth Surf. Proc. Land., 38, 902-907, doi:10.1002/esp.3412, 2013.
Ekemen, T. and Kacaroglu, F.: Hydrogeology of Tecer Mountain (Sivas-Ulas) springs, Cumhuriyet University, Eng. Faculty J., A2, 87-102, 2001.

Ekmekçi, M. Pesticide and nutrient contamination in the Kestel polje-Kirkgoz karst springs, Southern Turkey, Environ. Geol., 49, 19-29, doi:10.1007/s00254-005-0022-2, 2005.

Eris, E. and Wittenberg, H.: Estimation of baseflow and water transfer in karst catchments in Mediterranean Turkey by nonlinear recession analysis, J. Hydrol., 530, 500-507, doi:10.1016/j.jhydrol.2015.10.017, 2015.

Fiorillo, F.: Spring hydrographs as indicators of droughts in a karst environment, J. Hydrol., 373, 290-301, doi:10.1016/j.jhydrol.2009.04.034, 2009.

Fiorillo, F., Pagnozzi, M., and Ventafridda, G.: A model to simulate a recharge processes in karst massifs, Hydrol. Process., 29, 2301-2314, doi:10.1002/hyp.10353, 2015a.

Fiorillo, F., Petitta, M., Preziosi, E., Rusi, S., Esposito, L., and Tallin, M.: Long-term trend and fluctuations of karst spring discharge in a Mediterranean area (central-southern Italy), Environ. Earth Sci., 74, 153-172, doi:10.1007/s12665-014-3946-6, 2015b.

Fleury, P., Maréchal, J. C., and Ladouche, B.: Karst flash-flood forecasting in the city of Nîmes (southern France), Eng. Geol., 164, 26-35, doi:10.1016/j.enggeo.2013.06.007, 2013.

Freeze, A. R. and Cherry, A. J.: Groundwater, Prentice-Hall Inc., Englewood, London, UK, p. 604, 1979.

Gunay, G.: Hydrology and hydrogeology of Sakaryabasi karstic springs, Çifteler, Turkey, Environ. Geol., 51, 229-240, doi:10.1007/s00254-006-0321-2, 2006.

Gunay, G., Guner, N., and Tork, K.: Turkish karst aquifers, Environ. Earth Sci., 74, 217-226, doi:10.1007/s12665-015-4298-6, 2015.

Guner, F. and Guner, I. N.: Determination of hydrogeology of the karstic springs of Sakabasi by using hydrochemistry and environmental isotope techniques, Symposium on isotope techniques in hydrology, State Hydraulics Works, Adana, 207-229, 2002.

Gunn, J.: Contributory area definition for groundwater source protection and hazard mitigation in carbonate aquifers. Natural and Anthropogenic Hazards in Karst Areas: Recognition, Analysis, and Mitigation, Special Publication no. 279, Geological Society, London, 97-109, doi:10.1144/SP279.9, 2007.

Gutierrez, F., Parise, M., De Waele, J., and Jourde, H.: A review on natural and human-induced geohazards and impacts in karst, Earth Sci. Rev., 138, 61-88, doi:10.1016/j.earscirev.2014.08.002, 2014.

IPCC: Summary for Policymakers, in: Climate Change 2013: The Physical Science Basis. Contribution of Working Group I to the Fifth Assessment Report of the Intergovernmental Panel on Climate Change, edited by: Stocker, T. F., Qin, D., Plattner, G.-K., Tignor, M., Allen, S. K., Boschung, J., Nauels, A., Xia, Y., Bex, V., and Midgley, P. M., Cambridge University Press, Cambridge, UK and New York, NY, USA, p. 33, 2013.

Issar, A. S. and Passhier, R.: Regional hydrogeological concepts, in: Groundwater recharge. A guide to understanding and estimating natural recharge, IAH Int. Contrib. Hydrogeol. 8, edited by: Lerner, D. N., Issar, A. S., and Simmers, I., Heinz Heise, Hannover, 21-98, 1990.

Karaguzel, R. and Akinci, O. T.: Influence between geological environment and the settlement area, Isparta case, Symposium on 
Urbanization and Geology, 19-20 November 1998, Istanbul, 6175, 1998.

Karl, T. R., Melillo, J. M., and Peterson, T. C.: Global Climate Change Impacts in the United States, US Global Change Research Program, Cambridge University Press, p. 196, 2009.

Malard, A., Sinreich, M., and Jeannin, P. Y.: A novel approach for estimating karst groundwater recharge in mountainous regions and its application in Switzerland, Hydrol. Process., doi:10.1002/hyp.10765, in press, 2016.

Massei, N., Mahler, B. J., Bakalowicz, M., Fournier, M., and Dupont, J. P.: Quantitative interpretation of specific conductance frequency distribution in karst, Groundwater, 45, 288-293, doi:10.1111/j.1745-6584.2006.00291.x, 2007.

Mazor, E.: Applied chemical and isotopic groundwater hydrology, Open University Press, Celtic Court 22, Ballmoor, Buckingham, p. 274, 1991.

Milanovic, P. T.: Karst hydrogeology, Water Resources Publication, Littleton, Colorado, USA, p. 434, 1981.

OECD: Water and Climate Change Adaptation: Policies to Navigate Uncharted Waters, OECD Studies onWater, OECD Publishing, Paris, p. 112, doi:10.1787/9789264200449-en, 2013.

Ozyurt, N. N.: Residence time distribution in the Kirkgoz karst springs (Antalya-Turkey) as a tool for contamination vulnerability assessment, Environ. Geol., 53, 1571-1583, doi:10.1007/s00254-007-0811-x, 2008.

Palmer, A. N.: Understanding the hydrology of karst, Geol. Croat., 63, 143-148, doi:10.4154/gc.2010.11, 2010.

Parise, M.: Flood history in the karst environment of CastellanaGrotte (Apulia, southern Italy), Nat. Hazards Earth Syst. Sci., 3, 593-604, doi:10.5194/nhess-3-593-2003, 2003.

Parise, M.: Karst geo-hazards: Causal factors and management issues, Acta Carsologica, 44, 401-4014, 2015.

Parise, M. and Gunn, J.: Natural and anthropogenic hazards in karst areas: recognition, analysis and mitigation, Special Publication no. 279, Geological Society, London, p. 202, 2007.

Parise, M. and Sammarco, M.: The historical use of water resources in karst, Environ. Earth Sci., 74, 143-152, doi:10.1007/s12665014-3685-8, 2015.
Parise, M., Ravbar, N., Živanovic, V., Mikszewski, A., Kresic, N., Madl-Szonyi, J., and Kukuric, N.: Hazards in karst and managing water resources quality, Karst Aquifers Characterization and Engineering, in: Professional Practice in Earth Sciences, Springer, Switzerland, 601-687, doi:10.1007/978-3-319-128504_17, 2015.

Raeisi, E. and Karami, G.: Hydrochemographs of Berghan karst spring as indicators of aquifer characteristics, J. Cave Karst Stud., 59, 112-118, 1997.

Raynaud, F., Borrell-Estupina, V., Pistre, S., Van-Exter, S., Bourgeois, N., Dezetter, A., and Servat, E.: Combining hydraulic model, hydrogeomorphological observations and chemical analyses of surface waters to improve knowledge on karst flash floods genesis, Proc. IAHS, 369, 55-60, doi:10.5194/piahs-36955-2015, 2015.

Shuster, E. T. and White, W. B.: Seasonal fluctuations in the chemistry of limestone springs: a possible means of characterising carbonate aquifers, J. Hydrol., 14, 93-128, doi:10.1016/00221694(71)90001-1, 1971.

Stevanovic, Z.: Characterization of karst aquifer, Karst Aquifers - Characterization and Engineering, in: Professional Practice in Earth Sciences, Springer, Switzerland, 171-249, doi:10.1007/978-3-319-12850-4_6, 2015.

Sutcliffe, J. V.: Hydrology: A Question of Balance, IAHS Press, Centre for Ecology and Hydrology, Wallingford, Oxfordshire, UK, p. 200, 2004.

UNESCO: Archaeological Site of Sagalassos, http://whc.unesco. org/en/tentativelists/5409 (last access: 10 June 2016), 2009.

White, W. B.: Karst hydrology: recent developments and open questions, Eng. Geol., 65, 85-105, doi:10.1016/S00137952(01)00116-8, 2002.

Williams, N. H. and Lee, M.: Ireland at risk - Possible implications for groundwater resources of climate change, Groundwater Section, Geological Survey of Ireland, The Irish Academy of Engineering, Ireland, p. 18, 2008. 